\title{
Menumbuhkan Motivasi Belajar Warga Belajar Keaksaraan Fungsional di PKBM Wisata Kelurahan Pahandut Seberang Kota Palangka Raya
}

\author{
Wahidin ${ }^{*}$, Pintarsarna Telaumbanua \\ Program Studi Pendidikan Luar Sekolah, FKIP Universitas Palangka Raya, \\ Indonesia \\ Email: Wahidin@pls.upr.ac.id
}

Diterima: 16 Januari 2021; Disetujui: 29 Januari 2021; Diterbitkan: 2 Februari 2021

\begin{abstract}
ABSTRAK
Penelitian ini bertujuan untuk mendeskripsikan: 1) pelaksanaan pembelajaran keaksaraan fungsional, 2) upaya tutor dalam menumbuhkan motivasi belajar. Penelitian ini merupakan penelitian deskriptif dengan pendekatan kualitatif. Subyek penelitian yaitu pemilik lembaga, tutor dan warga belajar keaksaraan fungsional PKBM Wisata, Kelurahan Pahandut Seberang, Kota Palangka Raya. Metode pengumpulan data dengan wawancara, dan dokumentasi. Teknik analisis data yang digunakan reduksi data, display data dan pengambilan kesimpulan. Trianggulasi dilakukan untuk menjelaskan keabsahan data dengan menggunakan sumber. Hasil Penelitian Menunjukkan bahwa: (1) Pelaksanaan Pembelajaran pembelajaran keaksaraan fungsional yang di lakukan , pertama melakukan verifikasi calon tutor, dan calon peserta didik, kemudian tutor dan penyelenggara melakukan identifikasi kebutuhan sesuai kompetensi peserta, kedua tutor menyusun silabus serta rencana pelaksanaan pembelajaran, ketiga tutor menyiapkan bahan ajar dan modul yang diperlukan. (2) Upaya yang dilakukan untuk menumbuhkan motivasi warga belajar dengan cara memberikan pengarahan kepada warga belajar serta memberikan pelatihan yang dapat menunjang mereka untuk berwirausaha selain itu juga tutor dan pihak lembaga selalu memotivasi warga belajar dengan cara memberikan uang transportasi, hadiah, dan selalu menekankan kepada setiap warga belajar untuk lebih giat lagi dalam proses pembelajaran yang dilaksanakan oleh pihak lembaga.
\end{abstract}

Kata Kunci : motivasi belajar, program keaksaraan fungsional, dan upaya tutor

\section{PENDAHULUAN}

Pendidikan merupakan salah satu bentuk upaya untuk meningkatkan kualitas sumber daya manusia. Pendidikan dalam arti usaha sadar dan terencana untuk mewujudkan proses belajar sepanjang hayat, menyentuh semua sendi kehidupan, semua lapisan masyarakat, dan segala usia. Crow and Corw, berpendapat bahwa: "Pendidikan adalah proses yang berisi berbagai macam kegiatan yang cocok bagi individu untuk kehidupan sosialnya, membantu 
meneruskan adat dan budaya serta kelembagaan sosial dari generasi ke generasi". Sedangkan pengertian pendidikan menurut UU Nomor 20 tahun 2003 bab 1 ayat 1 dinyatakan bahwa pendidikan adalah : "usaha sadar dan terencana untuk mewujudkan suasana belajar dan proses pembelajaran agar peserta didik secara aktif mengembangkan potensi diri, kepribadian kecerdasan, akhlak mulia serta keterampilan yang diperlukan dirinya dan masyarakat". Berdasarkan beberapa pendapat tentang pengertian pendidikan di atas, dapat disimpulkan bahwa pada dasarnya pendidikan merupakan suatu usaha sadar yang dilakukan dengan proses mendidik, yakni proses dalam rangka mempengaruhi peserta didik agar mampu menyesuaikan diri sebaik mungkin dalam lingkungannya sehingga akan menimbulkan perubahan dalam dirinya, yang dilakuakan dalam bentuk pembimbingan, pengajaran, dan atau pelatihan. Pendidikan adalah segala upaya yang direncanakan untuk mempengaruhi orang lain baik individu, kelompok, atau masyarakat sehingga mereka melakukan apa yang diharapkan oleh pelaku pendidikan. UU RI No. 20 Tahun 2003 tentang Sistem Pendidikan Nasional, pasal 1 Menyatakan bahwa: "Pendidikan dilakukan dengan sadar dan terencana untuk mewujudkan suasana belajar dan proses pembelajaran agar peserta didik secara aktif mengembangkan potensi dirinya untuk memiliki kekuatan spiritual keagamaan, pengendalian diri, kepribadian, kecerdasan, akhlak mulia, serta keterampilan yang diperlukan dirinya, masyarakat, bangsa dan negara". Pendidikan formal sebagai salah satu lembaga pendidikan yang menjadi tumpuan harapan masyarakat untuk memperoleh pengetahuan dan keterampilan yang diinginkan ternyata mempunyai keterbatasan-keterbatasan, sehingga tidak mampu memenuhi semua tuntutan kebutuhan masyarakat. Sementara pendidikan luar sekolah, baik sebagai complement, suplement, maupun sebagai replacement pendidikan formal dapat melakukan banyak hal dalam menutupi jurang yang terjadi antara kebutuhan dan kenyataan (UU Sisdiknas No. 20 Tahun 2003). Pendidikan keaksaraan merupakan salah satu pendidikan nonformal, ini sesuai dengan Undang-Undang Dasar Negara Republik Indonesia Tahun 1945 No 20 Tahun 2003 bahwa program pendidikan nonformal meliputi, pendidikan kecakapan hidup, pendidikan anak usia dini, pendidikan kepemudaan, pendidikan pemberdayaan perempuan, pendidikan keaksaraan, pendidikan keterampilan dan pelatihan kerja serta pendidikan kesetaraan. Telah diakui bersama meratanya tuna aksara dikalangan orang dewasa di anggap sebagai kelompok masyarakat yang sangat berperan didalam masyarakat, jelas hal itu akan mempengaruhi pendapatan nasional dan kemajuan ekonomi, hal ini telah dipahami oleh orang-orang yang bertanggung jawab mengenai pendidikan. Undang-Undang Nomor 20 tahun 2003 tentang Sistem Pendidikan Nasional (Sisdiknas) menyebutkan jalur pendidikan terdiri atas pendidikan formal, nonformal dan informal. Pada Pasal 26 ayat (1) menyebutkan bahwa "pendidikan nonformal berfungsi sebagai pengganti, penambah dan/atau pelengkap pendidikan formal dalam rangka mendukung pendidikan sepanjang 
hayat. Penyelenggaraan layanan pendidikan nonformal diperlukan adanya pendidik salah satunya adalah tutor yang berperan dalam melaksanakan proses belajar mengajar pada pendidikan kesetaraan, pendidikan keaksaraan fungsional. Dalam rangka menjawab tantangan ke depan terkait dengan peningkatan mutu layanan pendidikan nonformal maka diperlukan kesiapan para tutor tersebut baik dari sisi kompetensi profesional, sosial, personal dan pedagogik. Para tutor harus senantiasa didorong untuk meningkatkan kompetensinya agar dapat menyesuaikan diri dan beradaptasi pada berbagai situasi di masyarakat. Keberagaman peserta didik pendidikan nonformal juga menuntut kemahiran para tutor untuk mampu meramu berbagai metode belajar dengan dilengkapi media belajar yang sederhana dan mudah dipahami oleh peserta didik. Pada ranah pendidikan masyarakat dari kalangan apapun, baik kalangan terendah sampai ke tingkat tinggi berhak memperoleh pendidikan yang bermutu. Dengan demikian, pendidikan dalam arti luas memang dapat dikatakan sebagai usaha makro, membangun masyarakat baik mengenai perekonomian, kemasyarakatan, kesehatan, kejiwaan dusamping juga membangun kebudayaan. Pendidikan yang memiliki arti tersebut menyentuh manusia secara umum, tanpa terikat oleh umur dan pekerjaanya, tentu saja terdapat pemikiran tentang pendidikan orang tua dan pemberantasan tuna aksara dikalangan mereka. Sihombing, (2000:53) "Pendidikan luar sekolah dirancang untuk membelajarkan masyarakat agar memiliki kecerdasan, keterampilan, dan kemandirian dalam bersikap sehingga mereka mampu menghadapi dan menyongsong perubahan yang akan datang dengan cepat yang mungkin tidak dapat diperhitungkan sebelumnya. Masyarakat dengan demikian mampu memecahkan persoalan yang dihadapi sebagai akibat dari perubahan dan memanfaatkannya untuk memperbaiki taraf dan mutu hidup dan kehidupannya". Pendidikan keaksaraan bukan hanya tanggung jawab suatu lembaga saja atau lembaga tertentu saja, akan tetapi tanggung jawab tersebut merupakan tanggung jawab seluruh orang tua, masyarakat dan pemerintah. Oleh karena itu, maka seluruh lembaga departemen, kelompok-kelompok sosial, perniagaan dan seluruh anggota masyarakat dalam menghadapi masalah pendidikan dan pemberantasan buta aksara. Kebutuhan pendidikan di dalam diri masyarakat sekarang ini sudah begitu tinggi. Tingginya kebutuhan tersebut, memang erat hubungannya dengan kesadaran pendidikan yang semakin kuat di dalam masyarakat, disamping itu juga karena perkembangan menyeluruh di dalam masyarakat yang semakin lama semakin cepat, seperti perkembangan ilmu dan teknologi, perkembangan ekonomi, perkembangan penduduk, perkembangan aspiras dan cita-cita hidup, perkembangan politik, sosio-budaya, serta perkembangan lingkungan alamiah. Bertolak dari kebutuhan pendidikan yang semakin tinggi di masyarakat, penyelesaian buta huruf tersebut mutlak harus dituntaskan dan diprioritaskan terlebih dahulu. Buta huruf erat kaitannya dengan masalah kebodohan, kemiskinan, keterbelakangan dan ketidakberdayaan. Agar pelaksanaan 
pemberantasan buta akasara ini dapat memenuhi hasil yang diharapkan, maka perlu dibentuk suatu program baru yang mampu menjembatani antara kebodohan (buta huruf) dan kemiskinan menjadi mampu baca, tulis, hitung dan sekaligus mampu berusaha mencari nafkah minimal untuk kehidupan dirinya dan keluarganya, yaitu "Program Keaksaraan Fungsional". Pembelajaran Keaksaraan Fungsional merupakan salah satu program pendidikan luar sekolah dalam hal ini sebagai salah satu upaya pendukung rencana strategi penurunan angka buta aksara. Program keaksaraan fungsional berfokus pada bagaimana cara masyarakat untuk menggunakan keaksaraan dalam kehidupan sehari-hari.Masyarakat tidak hanya membaca informasi yang bersifat fungsional, tetapi mereka juga perlu meningkatkan kemampuan untuk mendapatkan informasi dari bahan cetakan, menganalisa dan menulis pengalaman mereka sendiri. "Sihombing (2000) Kehadiran Pendidikan Luar Sekolah adalah sebagai usaha sadar yang diarahkan untuk menyiapkan, meningkatkan dan mengembangkan sumber daya manusia, agar memiliki pengetahuan, ketrampilan, sikap dan daya saing untuk merebut peluang yang tumbuh dan berkembang, dengan mengoptimalkan penggunaan sumber-sumber yang ada di lingkungannya". Motivasi belajar merupakan kekuatan mental yang mendorong terjadinya proses belajar. Lemahnya motivasi atau tiadanya motivasi belajar akan melemahkan kegiatan pembelajaran, hal ini akan membuat mutu belajar akan menjadi rendah. "Sudarwan (2002:2) Motivasi diartikan sebagai kekuatan, dorongan, kebutuhan, semangat, tekanan, atau mekanisme psikologis yang mendorong seseorang atau sekelompok orang untuk mencapai prestasi tertentu sesuai dengan apa yang dikehendakinya".

Sebagai pendidik, tutor sangat menunjang kelancaran pembelajaran keaksaraan fungsional untuk warga belajarnya. Sebagai motivator, fasilitator, dan mediator, tutor harus dapat mendorong dan menggerakkan kelompok sasaran (warga belajar) untuk ikutserta dalam kegiatan Pendidikan Luar Sekolah dengan segala kerelaan hati untuk meningkatkan pengetahuan, keterampilan, dan sikap mentalnya. Kelurahan pahandut seberang adalah pencahan dari Kelurahan Pahandut yang tertuang dalam peraturan Walikota Palangka Raya Nomor 23 Tahun 2003, pada saat pembentukannnya Kelurahan Pahandut seberang hanya berkantor dirumah warga yang bernama Fritma Jujur, Jalan, Pantai Cemara Labat 1, barulah pada tanggal 09 Agustus 2004 diresmikan sebagai Kantor Kelurahan Pahandut Seberang oleh Walikota Palangka Raya. Wilayah kelurahan Pahandut seberang terletak di daerah aliran sungai Kahayan dengan letak ketinggian kurang lebih 24 meter. Berkaitan dengan usaha diatas, maka didirikan suatu lembaga pembelajaran masyarakat, yaitu: Pusat Kegiatan Pendidikan Masyarakat (PKBM) yang diberi nama "WISATA “. PKBM ini secara resmi berdiri pada tanggal 28 Maret 2002 Pada dasarnya PKBM merupakan suatu wadah pembelajaran masyarakat yang merupakan tempat untuk menggerakkan segala potensi masyarakat agar mereka dapat menjadi 
masyarakat yang cerdas, terampil, dan mandiri. PKBM Wisata ini didirikan untuk memberikan pelayanan pendidikan di jalur luar sekolah kepada mereka yang tidak tertampung dijalur sekolah. Hal ini dilaksanakan dengan amanat UU No. 2 tahun 1989 tentang Sistem Pendidikan Nasional, yang sekarang diperbaharui dengan UU No. 20 Tahun 2003, bahwa Pendidikan Nasional itu dilaksanakan melalui jalur pendidikan formal, non formal, dan informal. Dari hasil observasi peneliti minat dan keaktifan warga belajar sangat minim dilihat dari sisi kehadiran, keaktifan dan motivasi warga belajar, dari sisi kehadiran dari total jumlah warga belajar sebanyak 20 orang yang hadir paling banyak kurang lebih 7 orang pada hal pada satu minggu proses pelaksanaan kegiatan belajar mengajar dilaksanakan dua kali seminggu yang dilaksanakan pada hari Rabu dan Sabtu Pukul 15.00 Wib.selain itu dilihat dari sisi keaktifan proses Tanya jawab atau interaktif dikelas sangat minim dilihat dari ketidakmampuan warga belajar bertanya kepada tutor ataupun menjelaskan sesuatu yang diberikan oleh tutor baik tugas maupun kerja kelompok, di lihat dari sisi motivasi dari dua pernyataan diatas peneliti bisa menyimpulkan bahwa tingkat motivasi dari warga belajar sangat rendah atau minim. Inilah alasan peneliti menjadikan topik penelitian ini sangat menarik. Akar permasalahan dari penelitaian ini terletak pada ketidakmampuan dan kurangnya motivasi para warga belajar di PKBM Wisata data ini peneliti mengambil dari hasil observasi yang telah di lakukan oleh peneliti. Kekurangan minat dan motivasi warga belajar menurut peneliti terletak pada dua sisi aslpek yang pertama pada ketidakmampuan tutor memberikan motivasi kepada seluruh warga belajar, yang ke dua dari sisi warga belajar itu sendiri dilihat belajar mengajar dari rasa malas bahkan mereka lebih mementingkan ijazah daripada proses. Peneliti ingin melihat apa faktor yang menjadi kelemahan tutor dalam memberikan motivasi maupun semangat kepada warga belajar selain itu peneliti juga ingin melihat proses pembelajaran yang di inginkan oleh warga belajar sehingga ada keselarasan antara proses pembelajaran yang diinginkan tutor dan keiginan warga belajar untuk mengikuti proses belajar mengajar. Penelitian ini lebih menarik karena melihat benang merah atau hubungan timbal balik antara tutor dengan warga belajar. Penelitian ini meniti beratkan pada peran tutor untuk membangun hubungan emosional (meningkatkan motivasi belajar) antara personal ke personal dan antara personal ke kelompok. Hal yang menarik lainnya adalah peneliti ingin melihat bagaimana sinergiritas antara tutor dan kelompok belajar dalam mengembangkan pusat kegiatan belajar Masyarakat (PKBM) berdasarkan analisis studi Pendidikan Luar Sekolah (PLS). Menariknya lagi peneliti ingin melihat bagaimana kualitas tutor dalam proses pembelajaran yang telah diberikan selama ini, selain itu peneliti ingin melihat bagaimana kualitas lulusan dari PKBM Wisata apakah ada perubahan kehidupan sosial atau sebaliknya. Inilah mengapa dalam penelitian ini sangat penting upaya tutor dalam menumbuhkan motivasi warga belajar keaksaraan fungsional. 
Penelitian ini penting karena ingin melihat bagaimana kinerja motivasi tutor dalam menumbuhkan motivasi warga belajar yang selama ini dalam segi pemantauan peniliti tidak memiliki motivasi dalam hal belajar atau tidak ada niat sama sekali untuk mengikuti proses belajar yang di selenggarakan oleh lembaga atau tutor, disini lah letak pentingnya penelitian ini bagi warga belajar dan tutor terhadap perkembangan ilmu pendidikan luar sekolah serta mencoba menulusuri apa faktor yang menjadi rendahnya motivasi warga belajar dalam konteks pendidikan luar sekolah.

\section{METODE PENELITIAN}

Dalam penelitian ini penulis menggunakan Jenis penelitian yang digunakan adalah kualitatif. Alasan bagi penulis metode kualitatif lebih menekankan pada pengamatan fenomena dan lebih meneliti ke subtansi makna dari fenomena tersebut. Analisis dan ketajaman penelitian kualitatif sangat terpengaruh pada kekuatan kata dan kalimat yang digunakan. Oleh karena itu, Basri (2014) menyimpulkan bahwa fokus dari penelitian kualitatif adalah pada prosesnya dan pemaknaan hasilnya. Perhatian penelitian kualitatif lebih tertuju pada elemen manusia, objek, dan institusi, serta hubungan atau interaksi di antara elemenelemen tersebut, dalam upaya memahami suatu peristiwa, perilaku, atau fenomena (Mohamed, Abdul Majid \& Ahmad, 2010).

Menurut Bogdan dan Taylor (1975:5) dalam Moleong (2001) mendefinisikan "metodelogi kualitatif" sebagai prosedur penelitian yang menghasilkan data deskriptif berupa kata - kata tertulis atau lisan dari orang orang dan perilaku yang dapat diamati. Menurut mereka, pendekatan ini diarahkan pada latar dan individu tersebut secara holistic (utuh). Jadi, dalam hal ini tidak boleh mengisolasikan individu atau organisasi ke dalam variabel atau hipotesis, tetapi perlu memandangnya sebagai bagian dari suatu keutuhan.

Peneliti secara aktif berinteraksi secara langsung dengan objek penelitian. Hal ini bertujuan untuk memotret dan melaporkan "e secara mendalam agar data yang diperolah lebih lengkap. Peneliti dapat menggunakan cara pengamatan langsung kepada objek penelitian dengan tujuan untuk menggali informasi sebanyak-banyaknya agar dalam pelaporan nanti dapat dideskripsikan secara jelas.

Penelitian ini dilakukan di lembaga Pusat Kegiatan Lembaga Masyarakat (PKBM) Wisata yang beralamatkan di Jl. Labat I Kelurahan Pahandut Seberang Kota Palangka Raya, Provinsi Kalimantan Tengah, merupakan salah satu Lembaga PKBM Wisata yang ada di pahandut seberang.

Menurut Lofland (Lexy Moleong 2012:157) sumber data utama dalam penelitian kualitatif adalah kata-kata dan tindakna selebihnya adalah tambahan seperti dokumen dan lainnya. Sumber data penelitian ini terdiri dari: Data primer adalah data yang di kumpulkan peneliti langsung dari sumber utama dan data 
adalah objek penelitian. Data yang di peroleh langsung dari objek penelitian merupakan data primer. Dalam penelitian ini pihak yang di jadikan informasi adalah yang di anggap mempunyai informasi (key-informan) yang di butuhkan di wilayah penelitian. Cara yang di gunakan untuk menentukan informasi kunci tersebut maka peneliti menggunakan "purposive sampling" atau sampling bertujuan, yaitu teknik sampling di gunakan oleh peneliti mempunyai pertimbangan-pertimbangan tertentu di dalam pengambilan sampelnya.

Data sekunder merupakan data yang diperoleh melalui pengumpulan atau pengolahan data yang bersifat studi dokumentasi (analisis dokumen) berupa penelaahnya terhadap dokumen pribadi, resmi kelembagaan, reverensi-reverensi atau peraturan (literatur laporan, tulisan dan lain-lain yang memiliki relevansi dengan focus permasalahan penelitian). Sumber data sekunder dapat dimanfaatkan untuk menguji, menafsirkan bahkan untuk meramalkan tentang organisasi tempat penelitian, data-data yang berhubungan dengan subyek yang diteliti serta dokumen yang berkaitan dengan penelitian.

Menurut Lexy. J Moleong, 2002:1003. Mendefenisikan bahwa analisa data penelitia adalah " Proses mengorganisasikan dan mentutorkan data dalam pola, kategori, dan suatu uaraian dasar sehingga dapat ditemukan tema dan dapat dirumuskan hipotesis kerja seperti yang di sarankan oleh data". Analisis data dalam penelitian kualitatif, dilakukan pada saat pengumpulan data berlangsung, dan setelah selesai pengumpulan data dalam periode tertentu. Pada saat wawancara, peneliti sudah melakukan analisis terhadap jawaban yang diwawancarai. Bila jawaban yang diwawancarai setelah dianalisis terasa belum memuaskan, maka peneliti akan melanjutkan pertanyaan lagi, sampai tahap tertentu, diperoleh data yang dianggap kredibel. Miles and Huberman, (1984), Aktivitas dalam analisis data kualitatif dilakukan secara interaktif dan berlangsung secara terus menerus sampai tuntas, sehingga datanya sudah jenuh. Aktivitas dalam analisis data, sehingga datanya sudah jenuh. Aktivitas dalam analisis data, yaitu data reduction, data display, dan conclusion: drawing/verification.

Peneitian kualitatif ini menggunakan langkah-langkah penelitian naturalistik, oleh karena itu analisis data dilakukan langsung di lapangan bersamaan dengan pengumpulan data. Menurut Sugiyono (2015: 256-266) Ada empat tahap analisis data yang diselingi dengan pengumpulan data yaitu : a) analisis domein, b) analisis taksonomi, c) analisis komponen, dan d) analisis tema.

\section{HASIL PENELITIAN DAN PEMBAHASAN}

Sejarah pembentukan kota Palangka Raya merupakan bagian integral dari pembentukan Provinsi Kalimantan Tengah berdasarkan Undang-Undang Darurat Nomor 10 Tahun 1957, yaitu tentang Pembentukan Daerah Swatantra Tingkat I Kalimantan Tengah pada tanggal 23 Mei 1957 yang menetapkan pembagian Provinsi Kalimantan Tengah dalam 6 (Enam) Kabupaten dan Palangka Raya 
sebagai ibukotanya. Sejak saat itu Provinsi Kalimantan Tengah resmi sebagai daerah otonom, sekaligus sebagai hari jadi Provinsi Kalimantan Tengah. Sedangkan tiang pertama Pembangunan kota Palangka Raya dilakukan oleh Presiden Republik Indonesia Soekarno pada tanggal 17 Juli 1957 dengan ditandai peresmian Monumen/Tugu Ibu Kota Provinsi Kalimantan Tengah di Pahandut. Kota Palangka Raya dikenal dengan motto "CANTIK" yang artinya Kota Palangka Raya merupakan sebuah kota yang terencana, Aman, Nyaman, Tertib, Indah dan memiliki Keterbukaan dalam arti luas kepada siapa saja. Kota Palangka Raya dinyatakan secara resmi sebagai Ibu Kota Provinsi Kalimantan Tengah pada tanggal 17 Juli 1975, dengan total luas wilayah $2.678,51 \mathrm{~km}^{2}$. Kota ini merupakan wilayah yang sangat luas untuk wilayah suatu kota. Sehingga selain wilayah perkotaan yang terletak di pusat kota, wilayah pedesaan sangat mendominasi Kota Palangka Raya. Dibagi dalam 5 (lima) kecamatan, yaitu: Kec. Pahandut, Sebangau, Jekan Raya, Bukit Batu dan Kecamatan Rakumpit. Luas Kecamatan Pahandut 117.25 km2; Luas Kecamatan Sabangau 583,5 km² Kecamatan Jekan Raya 352,62 km²; Kecamatan Bukit Batu $572 \mathrm{~km}^{2}$; dan Kecamatan Rakumpit seluas $1.053,14 \mathrm{~km}^{2}$. Pelaksanaan otonomi Daerah sebagai tindak lanjut berlakunya Undang- Undang No. 22 Tahun 1999 Tentang Pemerintahan Daerah dan pemekaran Kabupaten sebanyak 13 (tiga belas) Kabupatem, memberikan peluang dan tantangan bagi Pemerintah Kota berserta masyarakatnya untuk mengemban tugas dan tanggung jawab yang lebih luas, baik dalam bidang urusan pemerintahan maupun dalam pengelolaan pembangunan. Sebagai implikasi dari otonomi tersebut, maka berdasarkan Perda No. 32 tahun 2002 wilayah administrasi Kota Palangka Raya telah dilakukan pemekaran jumlah kecamatan dan jumlah kelurahan. Secara administratif Kota Palangka Raya dibagi menjadi 5 Kecamatan dan 30 Kelurahan. Secara Geografis kota Palangka Raya terletak diantara $113^{\circ} 30^{\circ e} \mathrm{~s} / \mathrm{d}$ $114^{\circ} 04^{\text {ee }}$ Bujur Timur dan $1^{\circ} 30^{\text {ee }} \mathrm{s} / \mathrm{d} 2^{\circ} 30^{\text {ec }}$ Lintang Selatan. Secara Administrasi berbatasan dengan Kabupaten Gunung Mas di sebelah Utara, Kabupaten Gunung Mas dan Kabupaten Pulang Pisau di sebelah Timur, Kabupaten Pulang Pisau di sebelah Selatan, dan Kabupaten Katingan di sebelah Barat Kota Palangka Raya memiliki iklim yang lembab dan panas (Tipe A dan B) temperature absolute maksimum mencapai $30^{\circ} \mathrm{C}$ dengan suhu rata-rata $26^{\circ} \mathrm{C}$. Curah hujan rata-rata $2.776-3.393 \mathrm{~mm}$ per tahun. Geologi wilayah kota Palangka Raya hampir seluruhnya ditempati oleh formasi batuan yang relatif berumur muda, yaitu plistosen hingga holosen. Formasi geologi yang ada di wilayah Kota Palangka Raya juga tersusun atas formasi Aluvium ( $Q a)$ (tersusun dari bahan-bahan liat kaolinit dan debu bersisipan pasir, gambut, kerakal dan bongkahan lepas, merupakan endapan sungai dan rawa) dan formasi Batuan Api (Trv) terdiri dari andesit basalt dan rijang. Selain kedua formasi tersebut, wilayah kota Palangka Raya juga termasuk ke dalam formasi Dahor (TQd) 
(tersusun atas sebagian besar pasir kuarsa dan dasar lempung, pada beberapa tempat terdapat sisipan konglomerat yang komponennya berupa batuan malihan, granit, dan lempung). Wilayah utara kota Palangka Raya struktur batuannya terbentuk dari endapan mineral batu kwarsa, kaolin dan granodiarit (batu gunung) yang memiliki sifat daya tekan yang kuat dan kestabilan tanah dan batuan yang tinggi. Sebaran batuan ini sebagian besar berada di Kecamatan Bukit Batu dan merupakan kawasan pertambangan dan galian. Jenis tanah yang terdapat di wilayah kota Palangka Raya meliputi podsol, regosol, organosol, aluvial, litosol, dan podsolik merah kuning yang menyebar di sekitar bentaran sungai dan danau. Jenis tanah yang terbentuk di suatu daerah dipengaruhi oleh struktur batuan induk yang oleh proses bio-fisik atau proses pelapukan akan membentuk jenis tanah tertentu. Oleh karena itusifat batuan secara geologis akan menentukan kesuburan tanah dan kemudian berpengaruh terhadap kesesuaian penggunaan. Sebagian besar kota Palangka Raya relatif datar (030\%), di wilayah Bukit Tangkiling Kecamatan Bukit Batu terdapat bukit berbatu dengan kemiringan lahan $>40 \%$. Berdasarkan peta topografi, ketinggian rata-rata kurang dari 60 meter dari permukaan laut. Kota Palangka Raya memiliki 3 sungai, yakni: Sungai Kahayan, Sungai Rungan, dan Sungai Sabangau. Pola aliran sungai tersebut memperlihatkan pola aliran meranting dengan stadium aliran dewasa hingga tua, yang ditandai oleh pola meander yang sangat kuat hingga membentuk danau-danau kecil sebagai akibat meander terpotong. Sungai Kahayan, Rungan dan Sabangau dengan anak-anak sungainya adalah prasarana transportasi alam yang sangat penting, karena sungai- sungai tersebut menghubungkan wilayah kota Palangka Raya dengan wilayah sekitarnya. Sebagian besar penduduk kota Palangka Raya memanfaatkan air permukaan dangkal (sumur) sebagai air untuk kebutuhan hidupnya (minum, memasak, dan mencuci), dan sebagian lagi memanfaatkan air sungai sebagai air bersih. Jumlah penduduk dipengaruhi oleh angka kelahiran, kematian dan perpindahan penduduk, baik penduduk masuk maupun keluar dari suatu daerah. Pada tahun Jumlah penduduk Kota Palangka Raya pada tahun 2018 sebanyak 283.612 jiwa. Angka ini meningkat dari tahun 2017 dengan tingkat pertumbuhan penduduk sebesar 2,88 persen. Dengan luas wilayah sekitar 2.853,5 km2 penambahan penduduk tersebut meningkatkan pula kepadatan penduduk Kota Palangka Raya yaitu menjadi sebanyak 99 jiwa setiap satu km2 .

\section{Pembahasan}

Pada bagian ini peneliti memuat gagasan peneliti, keterkaitan antara pola- pola, kategori-kategori, dan di mensi-dimensi, posisi temuan/teori terhadap teori dan temuan-temuan sebelumnya, serta penafsiran dan penjelasan dari temuan/teori yang di ungkap dari lapangan (grounded theory). Pembahasan temuan penelitian disesuiakan dengan fokus dan sub fokus penelitian yang telah disajikan pada bagian sebelumnya. 


\section{Pelaksanaan Pembelajaran Keaksaraan Fungsional di PKBM Wisata}

Berdasarkan hasil penelitian ditemukan bahwa pelaksanaan pembelajaran keaksaraan fungsional melakukan verifikasi calon tutor, dan calon peserta didik, kemudian tutor dan penyelenggara melakukan identifikasi kebutuhan sesuai kompetensi peserta, kedua tutor menyusun silabus serta rencana pelaksanaan pembelajaran, ketiga tutor menyiapkan bahan ajar dan modul yang diperlukan. Menurut Abdillah dalam Aunurrahman (2010:35) menyimpulkan bahwa belajar adalah suatu usaha sadar yang dilakukan oleh individu dalam perubahan tingkah laku baik melalui latihan dan pengalaman yang menyangkut aspek-aspek kognitif, afektif dan psikomotor untuk memperoleh tujuan tertentu. Dengan demikian dapat dikatakan bahwa belajar akan membawa perubahan-perubahan pada individu yang belajar, baik dari ilmu pengetahuan, keterampilan, sikap, minat, watak dan juga penyesuaian diri”. Menurut Sihombing (1999:21) "keaksaraan fungsional adalah pengembangan dari program pemberantasan buta huruf." Tujuan dari program ini adalah untuk meningkatkan keaksaraan dasar warga masyarakat buta aksara (warga belajar) sesuai dengan minat dan kebutuhan hidupnya. Kegiatan ini diselenggarakan untuk melayani warga masyarakat yang menyandang buta aksara, usia 10-44 tahun, dengan prioritas usia 17-30 tahun. Pelaksanaan kegiatan belajar mengajar dibantu oleh seorang tutor, materi pelajaran dan sarana belajar dikembangkan dan berkaitan dengan mata pencaharian warga belajar. Program keaksaraan fungsional di PKBM Wisata terdiri dari dasar dan lanjutan. Keaksaraan fungsional dasar hanya diberikan materi baca tulis hitung saja karena rata-rata warga belajar belum mengenal huruf. Keaksaraan fungsional lanjutan sudah diberikan pelatihan berupa membuat keterampilan Kue, dan Menjahit Waktu pelaksanaan pembelajaran keaksaraan fungsional di PKBM Wisata dilakukan setiap Kamis dan Sabtu pukul 15.00 sampai 16.00. Jumlah warga belajarnya adalah 1 kelompok belajar yang terdiri dari 20 orang, warga belajar terdiri dari ibu-ibu yang berusia 40-60 tahun. Warga belajar berasal Kelurahan Pahandut seberang. Kegiatan pembelajaran keterampilan fungsional diarahkan pada pemberian keterampilan yang bersifat ekonomi produktif dan keterampilan sosial. Menurut Pasaribu (2012) "keterampilan fungsional menjadi tekanan pada kegiatan pendidikan keaksaraan fungsional karena sebagian besar warga belajar sasaran program penuntasan buta aksara adalah masyarakat miskin, sehingga secara ekonomi perlu diberdayakan."

\section{Persiapan}

Persiapan pembelajaran Keaksaraan Fungsional di PKBM Wisata adalah penyelenggara melakukan verifikasi calon tutor dan calon peserta didik. Tutor bersama penyelenggara melakukan identifikasi kebutuhan berdasarkan minat dan potensi lokal. Tutor menyiapkan silabus dan rencana pelaksanaan 
pembelajaran (RPP KF) sesuai jenis materi yang dibelajarkan, dan mengacu pada standar kompetensi keaksaraan yang berbasis lokal. Tutor menyiapkan bahan ajar/modul dan media yang diperlukan untuk pembelajaran. Tutor menyiapkan bahan dan alat praktik. Aspek persiapan yang dilakukan sesuai dengan apa yang disampaikan oleh Kusnadi (2005:203), yaitu, perencanaan strategis pendidikan nonformal mencakup 1) tujuan yang jelas yang mencerminkan kebutuhan masyarakat, baik sosial, ekonomi cultural dan etika 2) pemanfaatan sumber-sumber yang memungkinkan pemanfaatnya yang dalam penelitian ini mencakup sarana-prasarana, media dan tutor dalam program keaksaraan keluarga 3) pelaksanaan perencanaan, dengan memperhatikan strategi perencanaan, yaitu analisis situasi dan identifikasi kebutuhan warga belajar 4) dan evaluasi dan umpan balik guna perencanaan program berikutnya.

\section{Pelaksanaan}

Menurut Kusnadi (2005) bahwa program Pelaksanaan pembelajaran keaksaraan harus mendorong masyarakat untuk merubah dirinya berorientasi kebutuhan yang nyata. Selain itu isi program harus mencerminkan masalahmasalah dan deskripsi teknis pemecahannya, penyampainnya harus kondusif dan memungkinkan suasana tukar pikiran pengalaman untuk menimbulkan partisipasi yang baik dari warga belajar. Dalam pelaksanaan pembelajaran keaksaraan fungsional di PKBM wisata dengan cara memberikan pelatihan dan pengenalan huruf bagi warga belajar keaksaraan fungsional serta memberikan rasa nyaman dengan cara mengayomi dan mengajak warga belajar keaksaraan fungsional, pelaksanaan pembelajaran yang dilakukan tutor dengan cara mengarahkan warga belajar satu persatu untuk bisa membaca, menulis dan berhitung serta memberikan pelatihan kepada warga belajar keaksaraan fungsional. Menurut Sujarwo (2008) bahwa tujuan dari pendidikan keaksaraan fungsional adalah untuk membantu warga belajar mencari dan menggunakan bahan calistung sendiri untuk mengembangkan kemampuan dan keterampilan membaca, menulis, berhitung dan berbahasa Indonesia yang dilengkapi dengan keterampilan fungsional sesuai dengan kehidupan sehari-hari. Pelaksanaan pembelajaran keaksaraan fungsional di PKBM Wisata dari bulan Maret 2020November 2020 selama 50 jpl. Terdiri dari 1 kelompok belajar yang berjumlah 20 warga belajar. Waktu pertemuan dua kali dalam seminggu yang berlangsung selama 1 jam. Metode dan bahan ajar yang digunakan antara lain diskusi, ceramah, tanya jawab, dan praktek langsung. Tutor keaksaraan fungsional di PKBM Wisata berjumlah 2 orang yang berpendidikan S1 dan SMA.

\section{Motivasi belajar warga belajar keaksaraan fungsional sebelum dilakukan upaya tutor}

Motivasi belajar warga belajar keaksaraan fungsional sebelum dilakukan upaya tutor cukup rendah, hal ini dapat diketahui dari indikator 
motivasi belajar yaitu ketekunan dalam belajar dan antusiasme warga belajar dalam mengikuti pembelajaran yang masih rendah. Walaupun dalam indikator motivasi belajar yang lain seperti ulet dalam menghadapi kesulitan, keinginan berprestasi dan kemandirian dalam belajar sudah cukup baik. Motivasi belajar merupakan faktor psikis yang bersifat non-intelektual. Peranannya yang khas adalah dalam hal penumbuhan gairah, merasa senang dan semangat untuk melakukan proses pembelajaran. Warga belajar yang memiliki motivasi kuat, akan mempunyai banyak energi untuk melakukan kegiatan pembelajaran. Menurut Sardiman (2011:75) "motivasi belajar merupakan kekuatan yang akan menggerakkan jasmani dan rohani seseorang untuk melakukan sesuatu demi tercapainya tujuan yang diinginkan." Selaras dengan pendapat sihombing (1992:21) mengemukakan pelaksanaan pembelajaran keaksaraan fungsional adalah pengembangan dari program pemberantasan buta huruf, berkaitan dengan penelitian yang sudah dilakukan peneliti bahwasanya pelaksanaan pembelajaran keaksaraan fungsional yang dilakukan tutor selama ini dengan cara mengajak dan mengayomi warga belajar dan juga tutor memberikan pelatihan dan pengenalan huruf seperti pengenalan abjad sehingga warga belajar setelah lulus dari kegiatan keaksaraan bisa membaca, berhitung dan mempunyai keakhlian dalam berwirausaha setelah lulus dari PKBM Wisata.

\section{Upaya Tutor dalam menumbuhkan Motivasi Belajar Keaksaraan Fungsional di PKBM Wisata}

Berdasarkan hasil penelitian ditemukan bahwa motivasi belajar warga belajar kelompok keaksaraan fungsional adalah variatif. Motivasi yang berbedabeda menggambarkan terdapat warga belajar yang memiliki motivasi variatif. Motivasi belajar warga kelompok keaksaraan fungsional tergolong variatif dibuktikan dengan melihat indikator motivasi. Indikator motivasi tersebut meliputi ketekunan dalam belajar, ulet dalam menghadapi kesulitan, minat dan ketajaman perhatian dalam belajar, berprestasi dalam belajar, dan mandiri dalam belajar. Dalam penelitian ini indikator motivasi di atas terbagi menjadi subindikator yang mampu menggambarkan motivasi warga belajar keaksaraan fungsional. Hal ini berarti indikator motivasi yang digunakan dalam penelitian ini diantaranya meliputi kehadiran, mengikuti proses belajar mengajar, belajar di rumah, sikap terhadap kesulitan, usaha mengatasi kesulitan, kebiasaan dalam mengikuti pelajaran, semangat dalam mengikuti proses belajar mengajar, keinginan untuk berprestasi, kualifikasi hasil belajar, penyelesaian tugas dan menggunakan kesempatan di luar jam pelajaran. Hasil temuan penelitian ini bahwa motivasi belajar warga kelompok keaksaraan bervariatif dapat digambarkan dengan terpenuhinya indikator motivasi yang digunakan. Motivasi yang bervariatif dapat dilihat dari aspek ketekunan dalam belajar berupa kehadiran warga belajar dalam kegiatan pembelajaran dan belajar di rumah. Kehadiran warga belajar dalam kegiatan pembelajaran berbeda-beda apabila 
dibandingkan dengan seluruh jumlah warga belajar keaksaraan fungsional pada setiapkelompok. Sedangkan belajar di rumah dimanfaatkan oleh warga belajar dengan pendampingan dari pihak keluarga. Motivasi belajar warga ditunjukkan dengan adanya sikap ulet dalam menghadapi kesulitan yang meliputi aspek sikap dan usahanya menghadapi kesulitan. Warga belajar keaksaraan fungsional memiliki kelutan dalam menghadapi kesulitan yang ditunjukkan dengan sikap keingintahuan melalui usaha bertanya kepada tutor. Motivasi warga belajar dapat ditunjukkan dengan adanya minat dan ketajaman perhatian dalam belajar yang meliputi kebiasaan dalam mengikuti pelajaran dan semangat dalam mengikuti proses belajar mengajar. Kebiasaan yang dilakukan oleh warga belajar meliputi kebiasaan bertanya, kebiasaan mengeluarkan pendapat, dan kebiasaan hanya sebatas mengikuti alur pembelajaran dengan mengikuti arahan dan bimbingan tutor. Sedangkan dilihat dari aspek semangat warga belajar adalah bervariasi. Motivasi belajar dapat ditunjukkan dengan adanya prestasi yang baik dalam belajar dimana meliputi aspek keinginan untuk berprestasi dan memiliki kualifikasi hasil belajar yang baik. Penelitian menunjukkan bahwa warga belajar memiliki keinginan berprestasi dan kualifikasi hasil belajar yang cukup baik, dilihat dari kajian dokumen warga belajar yang menunjukkan hasil yang cukup baik. Warga belajar yang memiliki motivasi belajar dapat ditunjukkan dengan kemandirian dalam belajar. Mandiri dalam arti warga belajar berupaya terhadap dirinya untuk mencapai hasil belajar yang baik. Mandiri dalam belajar dapat dilihat dari aspek penyelesaian tugas/ pekerjaan rumah dan menggunakan kesempatan di luar jam pelajaran. Penyelesaiam tugas/ pekerjaan rumah dilakukan oleh warga belajar secara langsung di tempat pembelajaran setelah pembelajaran selesai. Penggunaan kesempatan di luar jam pelajaran dimanfaatkan dengan belajar di rumah dengan bimbingan pihak keluarga dan mendatangi rumah tutor. Menurut Mc.Donald dalam Sardiman (2006: 73) motivasi adalah perubahan energi dalam diri seseorang yang ditandai dengan munculnya "feeling" dan didahului dengan tanggapan terhadap adanya tujuan. Pendapat yang sama diungkapkan oleh Ghullam Hamdu dan Lisa Agustina (2011:91) motivasi adalah suatu usaha yang didasari untuk menggerakkan, mengarahkaan dan menjaga tingkah laku seseorang agar ia terdorong untuk bertindak melakukan sesuatu sehingga mencapai hasil atau tujuan tertentu. Warga belajar kelompok keaksaraan fungsional telah memiliki motivasi dengan adanya perubahan dalam energi dengan ditandai dengan munculnya "feeling" dan didahului dengan tanggapan terhadap tujuan. Terdapat tanggapan atau respon yang baik oleh warga belajar untuk mengikuti kegiatan pembelajaran keaksaraan fungsional. Perubahan energi tersebut ditunjukkan dengan respon yang baik dengan bersedia mengikuti pembelajaran keaksaraan fungsional. Perubahan energi yang didahului oleh tanggapan terhadap tujuan yakni menambah ilmu dan meningkatkan keterampilan membaca dan menulis. Hal ini termasuk dalam adanya usaha warga belajar yang didasari untuk menggerakkan, 
mengarahkan dan menjaga tingkah laku sehingga terdorong untuk bertindak melakukan kegiatan belajar baik di tempat pembelajaran dengan bimbingan tutor maupun belajar di rumah dengan bimbingan pihak keluarga. Adanya dorongan untuk belajar sehingga mencapai hasil belajar belajar yang baik dan mencapai tujuan yakni peningkatan pengetahuan dan keterampilan membaca dan menulis. Motivasi warga belajar keaksaraan fungsional mengandung adanya keinginan yang mengaktifkan, menggerakkan, menyalurkan dan mengarahkan sikap dan perilaku individu belajar. Hal ini dibuktikan dengan adanya aktivitas belajar oleh warga belajar berdasarkan kesaran akan pentingnya ilmu pengetahuan yang bermanfaat bagi kehidupan sehari-hari. Hal ini senada dengan pendapat Santrock dan Yussen (Sugihartono, dkk, 2012: 74) bahwa belajar sebagai perubahan yang relatif permanen karena adanya pengalaman. Dalam motivasi terkandung adanya keinginan yang mengaktifkan, menggerakkan, menyalurkan dan mengarahkan sikap dan perilaku individu belajar (Dimyati dan Mudjiono, 2006: 80). Warga belajar memiliki motivasi belajar sehingga adanya keadaan internal tersebut mampu menumbuhkan gairah, merasa senang dan semangat untuk belajar. Motivasi belajar warga belajar keaksaraan fungsional ialah untuk meningkatkan ilmu pengetahuan dan keterampilan membaca menulis yang menjadi dasar warga belajar melakukan kegiatan belajar. Hasil penelitian ini mendukung pernyataan Sardiman (2006: 75) bahwa peranan yang khas adalah dalam hal penumbuhan gairah, merasa senang dan semangat untuk belajar. Motivasi belajar warga kelompok keaksaraan fungsional yang bersifat variatif tersebut digambarkan dengan terpenuhinya beberapa indikator motivasi. Motivasi belajar warga keaksaraan fungsional dilihat dari indikator ketekunan dalam belajar yang meliputi subindikator kehadiran saat pembelajaran dan belajar di rumah. Kehadiran warga belajar dalam kegiatan pembelajaran berbeda- beda pada setiap pertemuan apabila dibandingkan dengan seluruh jumlah warga belajar keaksaraan fungsional pada setiap kelompok. Berdasarkan hasil temuan dalam penelitian kehadiran yang berbeda-beda disebabkan oleh beberapa faktor. Faktor-faktor penyebab kehadiran variatif bersifat eksternal atau berasal dari luar diri warga belajar. Faktor-faktor tersebut ditemukan oleh peneliti saat mengamati pembelajaran keaksaraan fungsional banyak warga belajar yang tidak hadir dengan berbagai alasan diantaranya kesibukan bekerja yang belum selesai pada saat jam pembelajaran, kepentingan keluarga misalnya alasan mengurus anak dan suamu, dan kepentingankepentingan di masyarakat. Ketekunan dilihat dari dari upaya warga belajar untuk melaksankan kegiatan belajardi rumah. Upaya tersebut bertujuan untuk mengasah kemampuan dan keterampilan membaca menulis serta sebagai upaya pengingat sehingga tidak mudah lupa mengingat sebagian besar warga belajar merupakan ibu ibu. Motivasi belajar warga ditunjukkan dengan adanya sikap ulet dalam menghadapi kesulitan yang meliputi aspek sikap dan usahanya menghadapi kesulitan. Warga belajar keaksaraan fungsional memiliki 
keuletan dalam menghadapi kesulitan yang ditunjukkan dengan sikap keingintahuan melalui usaha bertanya kepada tutor. Saat pembelajaran berlangsung kegiatan yang dilakukan ialah berupa transfer ilmu pengatahuan dari tutor kepada warga belajar maupun sebaliknya. Dalam aktivitas tersebut seringkali warga belajar menjumpai kesulitan baik dalam menulis maupun membaca apa yang ditulis oleh tutor. Munculnya kesulitan yang dialami warga belajar mendorong adanya sikap ingin tahu. Sikap ingin tahu ditunjukkan oleh warga belajar melalui usaha bertanya kepada tutor. Warga belajar tidak merasa sungkan ataupun malu bertanya kepada tutor karena telah terjalin hubungan yang akrab dan kekeluargaan. Motivasi belajar warga dapat ditunjukkan dengan adanya minat dan ketajaman perhatian dalam belajar yang meliputi kebiasaan dalam mengikuti pelajaran dan semangat dalam mengikuti proses belajar mengajar. Kebiasaan yang dilakukan oleh warga belajar meliputi kebiasaan bertanya, kebiasaan mengeluarkan pendapat, dan kebiasaan hanya sebatas mengikuti alur pembelajaran dengan mengikuti arahan dan bimbingan tutor. Kebiasaan bertanya termasuk ke dalam sikap dan usaha dalam menghadapi kesulitan namun tergolong sebagai kebiasaan karena aktivits bertanya tersebut terjadi secara berulang-ulang pada setiap pembelajaran. Aktivitas bertanya merupakan hal biasa yang dilakukan oleh warga belajar. Beberapa warga belajar juga sering mengeluarkan pendapatnya terkait materi yang mereka ingin dapatkan dan bermanfaat bagi kehidupan sehari-hari. Hal ini berdasarkan hasil wawancara beberapa warga belajar, dimana juga dilihat melalui kegiatan observasi dari kesungguhannya dalam mengikuti kegiatan pembelajaran. Hasil pengamatan melalui observasi ditemukan bahwa tingkat semangat dalam mengikuti pembelajaran terdapat beberapa warga belajar hadir tepat waktu dan lainnya hadir melebihi waktu yang disepakati. Motivasi belajar dapat ditunjukkan dengan adanya prestasi yang baik dalam belajar dimana meliputi aspek keinginan untuk berprestasi dan memiliki kualifikasi hasil belajar yang baik. Penelitian menunjukkan bahwa warga belajar memiliki keinginan berprestasi dan kualifikasi hasil belajar yang cukup baik, dilihat dari kajian dokumen warga belajar yang menunjukkan hasil yang cukup baik. Adanya keinginan berprestasi berupa keinginan peningkatan pengetahuan dan keterampilan membacadan menulis berdasarkan hasil wawancara oleh peneliti. Keinginan berprestasi tersebut dibuktikan dengan kualifikasi hasil belajar yang baik. Hal ini dilihat dari kajian dokumen hasil tugas warga belajar. Warga belajar yang memiliki motivasi dapat ditunjukkan dengan kemandirian dalam belajar. Mandiri dalam arti warga belajar berupaya terhadap dirinya untuk mencapai hasil belajar yang baik. Mandiri dalam belajar dapat dilihat dari aspek penyelesaian tugas/ pekerjaan rumah dan menggunakan kesempatan di luar jam pelajaran. Penyelesaiam tugas/ pekerjaan rumah dilakukan oleh warga belajar secara langsung di tempat pembelajaran setelah pembelajaran selesai. Sebagian warga belajar dengan segera mengerjakan tugas dari tutor. Hasil penelitian di atas sesuai 
dengan indikator motivasi oleh Keke (2008) yang menyebutkan bahwa indikator motivasi antara lain ketekunan dalam belajar, ulet dalam menghadapi kesulitan, minat dan ketajaman dalam belajar, berprestasi dalam belajar dan mandiri dalam belajar. Hasil temuan tentang motivasi belajar diperkuat dengan adanya hasil penelitian oleh Aritonang Keke pada tahun 2008 bahwa minat dan motivasi belajar besar sekali pengaruhnya terhadap hasil belajar, faktor lain yang berpengaruh adalah cara mengajar pendidik terkait pemberian motivasi, karakter pendidik, suasana pembelajaran dan fasilitas belajar yang digunakan.

\section{KESIMPULAN}

Berdasarkan uraian hasil penelitian dan pembahasan yang telah disampaikan di Bab IV, maka dapat diambil kesimpulan sebagai berikut: 1) Pelaksanaan pembelajaran keaksaraan fungsional di PKBM Wisata melakukan verifikasi calon tutor, dan calon peserta didik, kemudian tutor dan penyelenggara melakukan identifikasi kebutuhan sesuai kompetensi peserta, kedua tutor menyusun silabus serta rencana pelaksanaan pembelajaran, ketiga tutor menyiapkan bahan ajar dan modul yang diperlukan. 2) Upaya yang dilakukan tutor dalam menumbuhkan motivasi belajar warga belajar keaksaraan fungsional di PKBM Wisata sangat efektif dan dapat diterima dengan baik oleh warga belajar. Upaya yang dilakukan tutor tersebut seperti, memberikan motivasi secara pribadi kepada warga belajar mengenai manfaat membaca, menulis dan berhitung serta memberikan pelatihan dan keterampilan yang dapat menunjang warga belajar. Memberikan reward berupa dana transportasi begitu juga uang untuk membeli hadiah berupa kebutuhan dapur. Yang dilakukan tutor tersebut warga belajar pun dapat termotivasi dalam mengikuti pembelajaran keaksaraan fungsional di PKBM Wisata. Selain itu juga tutor memberikan motivasi dengan cara memberikan pengarahan kepada warga belajar serta memberikan pelatihan yang dapat menunjang warga belajar untuk berwirausaha setelah lulus dari PKBM Wisata.

\section{Saran}

Berdasarkan hasil penelitian ini, ada beberapa saran yang peneliti ajukan, diantaranya: 1) Perlu adanya monitoring dan evaluasi secara berkala oleh pihak pengelola PKBM terhadap program keaksaraan fungsional pada setiapkelompok belajar untuk menjaga keberlanjutan program. Pihak lembaga PKBM hendaknya menambah pertemuan dalam pembelajaran keaksaraan fungsional yang hanya dilakukan dua kali seminggu, misalnya pembelajaran dilakukan seminggu 3 kali. Hal ini akan bermanfaat dan mempermudah warga belajar dalam memahami materi yang diberikan tutor. Selain itu Pihak Lembaga PKBM sendiri hendaknya lebih memperluas serta menjalin kerjasama dengan pihak-pihak terkait seperti Dinas Pendidikan Kabupaten, Provinsi ataupun dengan Kementerian Pendidikan Dan Kebudayaan Pusat. Hal ini akan bermanfaat 
bagi keberlanjutan program-program yang ada di PKBM khususnya program keaksaraan fungsional, sehingga program akan terus berlanjut dan berkembang di masa mendatang. Masyarakat luas hendaknya selalu tanggap dan merespon segala bentuk pendidikan. Pendidikan tidak hanya berada pada jalur formal, pendidikan non formal pun saat ini sudah sangat berkembang da manfaatnya sudah bisa dirasakan masayarakat luas. Oleh karena itu masyarakat yang masih buta aksara harus mendapatkan pendidikan agar terhindar dari buta aksara. Hal ini dapat dilakukan dengan bergabung dengan pendidikan non formal lewat program keaksaraan fungsiona yang sudah diselenggarakan di Sanggar Kegiatan Belajar (SKB) serta PKBM daerah setempat. 2) Tutor hendaknya lebih menambah variasi dalam memberikan upaya-upaya dalam menumbuhkan motivasi belajar. Variasi dapat dilakukan dalam bentuk memberikan hadiah/reward secara langsung kepada warga belajar yang berprestasi baik, sehingga hal itu dapat lebih memacu motivasi belajar warga belajar. Tutor hendaknya harus lebih teliti dalam pelaksanaan pembelajaran keaksaraan fungsional yang meliputi persiapan, pelaksanaan dan penilaian, agar hasil pembelajaran benar-benar baik dan efektif untuk warga belajar. Hal ini dikarenakan tutor memegang peranan yang penting dalam memenuhi kebutuhan pendidikan warga belajar. Pihak lembaga PKBM hendaknya lebih mensosialisasikan akan pentingnya program keaksaraan Tutor sebaiknya lebih memperhatikan kondisi warga belajar setelah program selesai. Tutor harus memantau perkembangan warga belajar, dengan pendidikan calistung yang sudah diberikan apakah dapat diaplikasikan dengan baik oleh warga belajar dalam kehidupan sehari-hari.

\section{DAFTAR PUSTAKA}

Aritonang, Keke T. (2008). "Minat dan Motivasi dalam Meningkatkan Hasil Belajar Siswa”. Jurnal Pendidikan Penabur (Nomor 10 tahun 7). Hlm. 11-21

Basri, Yuswar Zainul \& Mulyadi Subri. 2005. Keuangan Negara dan Analisis Kebijakan Utang Luar Negeri. Jakarta: PT. Raja Grafindo Persada

Bogdan, R. C. \& Biklen, S. K. (1982). Qualitative Research for Education: An. Introduction to Theory and Methods. Boston: Allyn and Bacon, Inc. Dimyati dan Mudjiono. (2009). Belajar dan Pembelajaran. Jakarta: Rineka Cipta Emda, A. (2018). Kedudukan Motivasi Belajar Siswa Dalam Pembelajaran. Lantanida Journal, 5(2), 172. https://doi.org/10.22373/lj.v5i2.2838

Fauzi. (2011). Pamong Belajar Pendidik Pengkaji Program dan Pengembang Model.

Hadiyanti, P. (2011). Penerapan Strategi Pemberdayaan Masyarakat Melalui Program Keterampilan Produktif Di Pkbm Rawasari. Jiv, 6(2), 126135 https://doi.org/10.21009/jiv.0602.3

Hamalik, Oemar. (2003). Proses Belajar Mengajar. Bandung : Bumi Aksara. 
Hermiyanty, Wandira Ayu Bertin, D. S. (2019). Interaksi Sosial Dan Pesan Budaya Sebagai Landasan Pendidikan. Journal of Chemical Information and Modeling, 12(1), 135-140.

Kusnadi. (2005). Pendidikan Keaksaraan, filosofi, strategi, implementasi. Jakarta: Direktorat Pendidikan Masyarakat.

Miles, M. B. \& Huberman, M. (1992). Qualitative Data Analysisis. Terjemahan Tjejep Rohendi Rohidi. Jakarta: UI-Press.

Moleong, L. J. (2016). Metodologi Penelitian Kualitatif Edisi Revisi. Bandung: PT. Remaja Rosdakarya Offset.

(2016). Metodologi Penelitian Kualitatif. Bandung:

Remaja Rosdakarya.

2016. Metodelogi Penelitian Kualitatif Edisi Revisi. Bandung: PT. Remaja Rosdakarya.

Mulyasa, E. (2003). Kuriklum Berbasis Kompetensi : Remaja Rosdakarya.

Nainggolan S, Lilis. (2012). Pendidik dan Tenaga Kependidikan PLS.

Pasaribu, Maripauli. (2012). Pembelajaran Keaksaraan Fungsional.

Prasetyo, lis. (2009). Pengembangan PKBM. Diakses dari http://iisprasetyo.blogspot.com/2009/06/pengembangan-pkbm.html. pada tanggal 01 Februari 2020, Jam 17.41 WIB.

Sardiman, A. (2011). Interaksi dan Motivasi Belajar Mengajar. Jakarta: CV. Rajawali Pers.

Sihombing, Umberto (2000). Pendidikan Luar Sekolah Manajemen Strategi Bandung: PD Mahkota.

Silalahi, U. (2010). Metode Penelitian Sosial. Bandung: PT Refika Aditama.

Sudjana, D. (2001). Pendidikan Luar Sekolah, Wawasan, Sejarah Perkembangan Falsafah dan Teori Pendukung Asas. Bandung: Falah Production.

(2003). PKBM dalam Memberdayakan Masyarakat. Jakarta: Visi Dirjen PLS

Sutopo H.B.. 2006. Metodologi Penelitian Kualitatif. Surakarta: Universitas Negeri Sebelas Maret.

Sugiyono. 2007. Metode Penelitian Kuantitatif Kualitatif dan $R \& D$. Bandung: Elfabeta.

Sugiyono. (2015). Metode Penelitian Pendidikan Pendekatan Kuantitatif, Kualitatif, dan $R \& D$. Bandung: Alfabeta.

Suprihatin, S. (2015). Upaya Guru Dalam Meningkatkan Motivasi Belajar Siswa. PROMOSI (Jurnal Pendidikan Ekonomi), 3(1), 73-82.

Syarif, Anwar. (2012). Fungsi dan Tugas Tenaga Kependidikan Undang-undang No 20 Tahun 2003 tentang Sistem Pendidikan Nasional. Yogyakarta : Pustaka Belajar 